\title{
Detección de los vinus PLRV, PVY, PVX y PVS en brotes de tubéraulos depapa por la técnica serológica de ELISA
}

\author{
Yorman Rodríguez de Estrada *, Eduardo Ortega C. **, Gustavo Trujillo ***
}

\section{RESUMEN}

Se utilizó ELISA en la modalidad de doble capa de anticuerpo, para detectar los virus PLRV, PVY, PVX y PVS en brotes de tubérculos de los cultivares Andinita y Granola en el estado de Mérida. Se evaluaron las clases de semilla Genética, Básica, Registrada, Certificada Nacional (N), y tipo pasilla para Andinita, incluyendo además Certificada Importada (I) para Granola. En el estado de Lara los cultivares fueron Kennebec en las clases Genética, Certificada (N) y Certificada (I) y Sebago con Básica y Certificada (I). Para cada clase se evaluaron 50 tubérculos, a nivel de laboratorio. De cada tubérculo se tomó el brote apical y uno lateral de aproximadamente $1 \mathrm{~cm}$. de longitud. Los resultados de laboratorio indicaron que el virus detectado con mayor frecuencia para Granola fue el PVS. Se observó la mayor incidencia en la clase Certificada (N) y Certificada (I). El PVS y la infección doble PVX + PVS fueron los más frecuentes en Kennebec y Sebago. La mayor incidencia de PVS fue en Certificada (I) para ambos cultivares y la infección doble PVX + PVS fue en Certificada (I) de Sebago. En Andinita no se detectó ninguno de los cuatro virus.

Palabras claves adicionales: detección, PLRV, PVY, PVX, PVS, evaluación de semillas

Aceptado para publicación : agosto 29, 1996

* FONAIAP - Centro de Investigaciones Agropecuarias del Estado de Lara

** FONAIAP - Estación Experimental Monagas

*** Universidad Central de Venezuela 


\title{
Detection of PLRV, PVY, PVX and PVS Viruses in Potato Tuber Sprouts Using the ELISA Serological Technique
}

\begin{abstract}
SUMMARY
Elisa technique of double layer of antibody was used to detect PLRV, PVY, PVX and PVS in potato tuber sprouts of Andinita and Granola cultivar at Mérida State in Venezuela. The evaluation was made in the following classes of potato seeds: Genetic, Basic, Registered, National Certified (N), "Pasilla” (small tubers) for Andinita and Imported Certified (I) for Granola. In Lara State the cultivars evaluated were: Kennebec National Certified (N) and Imported Certified (I) and Sebago Basic and Imported Certified (I). For each class 50 potato tubers were evaluated at laboratory level. The apical sprout and one of the lateral sprouts of $1 \mathrm{~cm}$ approximately, were taken from each tuber. The results of the laboratory indicated a higher frequency of detection of PVS in Granola. The higher incidence was observed in the National Certified (N) and Imported Certified (I) classes. The PVS and the double infection PVX + PVS were more frequent in Kennebec and Sebago. The higher incidence of PVS was in Imported Certified (I) for both cultivars and the double infection of PVX + PVS was for Imported Certified (I) of Sebago. None of the four viruses were detected in the Andinita cultivar.
\end{abstract}

Additional index words: detection, PLRV, PVY, PVX, PVS, seed evaluation.

\section{INTRODUCCIÓN}

La papa (Solanum tuberosum L.), es un cultivo de mucha importancia en la alimentación humana; ocupa el cuarto lugar entre los principales cultivos alimenticios en el mundo (Horton, 1987). En Venezuela ocupa el octavo lugar por su producción total y el noveno lugar por el valor económico de su producción (Ortega, 1989,1988). La semilla de calidad constituye el insumo más importante en la explotación del cultivo; sin embargo, debido a su forma de propagación asexual la misma está sometida a un alto riesgo de contaminación por virus, hongos, bacterias e insectos, durante el período de cultivo y almacenamiento,. Las enfermedades virales generalmente reducen el vigor de la planta y afectan su rendimiento. Hasta el presente, se han 
encontrado infectando a la papa más de 27 virus y un viroide (Abad, 1986; Hooker, 1982; Fribourg, 1980).

La papa en Venezuela es afectada probablemente por muchos virus, siendo los más importantes el del enrollamiento de la hoja (PLRV), el virus del mosaico severo (PVY), el virus del mosaico latente (PVX) y el virus S de la papa (PVS) (Ortega, 1988, 1989; Achutegui, 1982; Escobar, 1982; Debrot, Lastra y Ladera, 1980; Debrot y de la Rosa, 1980; Debrot, 1975): Sin embargo, la calidad fitosanitaria de la semilla en relación a la presencia de virus, antes de llevarse a la siguiente etapa de multiplicación en algunas localidades se desconoce en detalle, siendo la detección del virus en los materiales de propagación un aspecto fundamental para el control. Existen varios métodos de detección, algunos más confiables que otros.

Generalmente, las pruebas serológicas son preferidas en diagnóstico de virus debido a su adaptabilidad para probar un gran número de muestras. ELISA es el método serológico más sensitivo actualmente en uso y permite estimar cuantitativamente la concentración de virus en las muestras (Salazar, 1986; Clark y Adams, 1977). El presente trabajo tuvo como objetivo determinar la presencia de virus mediante la técnica ELISA en las distintas clases de semilla de papa que se importan y producen en el país.

\section{MATERIALESY MÉTODOS}

El trabajo experimental se realizó en las instalaciones del laboratorio de bacterias fitopatógenas y virología del Instituto de Botánica de la Facultad de Agronomía de la Universidad Central de Venezuela (UCV), Maracay, Venezuela.

Toma de Muestras: Se recolectaron muestras de tubérculos de papa de las distintas clases de semilla importada y nacional sembradas en las localidades de Mucuchíes y Santo Domingo, (estado de Mérida) y en Pueblo Hondo en el estado de Táchira (regiones de la Cordillera Andina) y en Cubiro y Sanare, en el estado de Lara.

Las muestras tomadas en la zona Andina fueron de los cultivares Granola procedente de Alemania y Andinita de producción nacional (Venezuela). El muestreo de los tubérculos de las clases Prebásica y Básica de Granola, se realizó en los invernaderos de la sub- estación de Pueblo Hondo de la Estación Experimental Táchira del Fondo Nacional de Investigaciones Agropecuarias (FONAIAP). La clase Certificada Nacional y el tipo "pasilla" se recolectaron en campos de productores en las localidades de Mucuchíes y Santo Domingo. Para la clase Certificada Importada el muestreo se realizó en un almacén con semilla importada. 
Para la clase Prebásica de Andinita, el muestreo se realizó en los invernaderos del Campo Experimental de Mucuchíes (FONAIAP). Las clases Básica, Registrada, Certificada Nacional y tipo "pasilla" fueron muestreadas en campos de productores de Santo Domingo y Mucuchíes. Las muestras de tubérculos recolectadas en el estado de Lara, fueron de los cultivares Kennebec y Sebago, ambos de procedencia canadiense. Las muestras de las clases Básica de Sebago y Prebásica de Kennebec se tomaron en los invernaderos de producción de semilla del Campo Experimental Las Cuibas (FONAIAP) en Cubiro. La clase Certificada Nacional de Kennebec fue tomada en la finca de un productor semillerista en la localidad El Páramo (1,700 msnm), en Cubiro. La papa Certificada Importada de ambos cultivares fue muestreada en un almacén de semilla importada, en la localidad de Sanare. Se seleccionaron al azar, por clase, 370 tubérculos, de los cuales a su vez se tomaron 50 tubérculos para someterlos a la detección de los virus PLRV, PVY, PVX y PVS.

Manejo de las Muestras y Detección de virus: Los 50 tubérculos se almacenaron, por clase, en bandejas plásticas bajo condiciones de protección de insectos vectores y luz difusa para estimular la brotación. Cuando los brotes alcanzaron una longitud de aproximadamente $1 \mathrm{~cm}$, los tubérculos fueron divididos en sub-muestras de cinco tubérculos para obtener un total de 10 sub-muestras por clase. De cada tubérculo se tomó el brote apical y uno lateral, formando así 10 brotes por sub-muestra. Se colocaron en bolsas plásticas para el procesamiento y detección de los virus en estudio por la técnica serológica ELISA ${ }^{1}$. Para la serología se utilizó la metodología descrita en el manual de instrucciones de equipo para diagnóstico por ELISA, del CIP.

\section{RESULTADOS Y DISCUSIÓN}

En las muestras de brote apical y lateral, en las distintas clases de semilla Granola, se encontró con mayor incidencia el virus S de la papa, en la clase Certificada Nacional, de 10 muestras cinco resultaron positivas (Tabla 1). Cabe destacar que el material de esta clase se encontraba almacenado en los galpones de El Pico "El Águila" (4,118 msnm), Mérida, aunque su procedencia era de campos semilleristas de la localidad de Tuñame, estado Trujillo y este virus se disemina principalmente por contacto de tubérculos o en el campo al rozar plantas sanas y enfermas (Beemster y Bokx, 1987; Bagnall, 1980), o también se perpetua por tubérculos infectados (Bagnall, 1980; Wetter, 1971). Esta clase es la progenie de semilla de Fundación importada desde Holanda, pudiendo ser una fuente de material infectado, debido a que si se observa la Tabla 1 , la clase que también presenta el virus S de la papa es la Certificada Importada, indicando esto que el material importado no viene totalmente libre de virus $\mathrm{S}$.

\footnotetext{
${ }^{1}$ Kits suministrados por el Centro Internacional de la Papa (CIP) 1990
} 
En este cultivar, no se presentaron PVX, PVY y PLRV, en ninguna de las clases a nivel laboratorio y los resultados son confiables debido a la precisión de la técnica serológica ELISA, al ser usada a nivel de brotes para detectar PVX, PVS, PVY, PLRV y obtener mejores resultados que con otros métodos según lo señalado por Maat y Huttinga (1987). Al utilizar los brotes apical y lateral se obtuvo reacción a la presencia de virus, confiable y persistente para PVS; esto concuerda con los resultados señalados por Banttari y Franco (1982).

Tabla 1. Muestras infectadas y sanas de brotes de tubérculos en el cultivar Granola, Mucuchíes, estado de Mérida, 1991.

\begin{tabular}{lccccc}
\hline & Muestras* & \multicolumn{4}{c}{ Muestras Infectadas y Sanas } \\
\cline { 5 - 6 } Clases de semilla & $\mathrm{N}^{\circ}$ & PVX & PVS & PVY & PLRV \\
\hline Genética (Prebásica) & 10 & $0 / 10$ & $0 / 10$ & $0 / 10$ & $0 / 10$ \\
Básica & 10 & $0 / 10$ & $0 / 10$ & $0 / 10$ & $0 / 10$ \\
Registrada & 10 & $0 / 10$ & $0 / 10$ & $0 / 10$ & $0 / 10$ \\
Certificada (N) & 10 & $0 / 10$ & $5 / 10$ & $0 / 10$ & $0 / 10$ \\
Certificada (I) & 10 & $0 / 10$ & $3 / 10$ & $0 / 10$ & $0 / 10$ \\
Pasilla & 10 & $0 / 10$ & $0 / 10$ & $0 / 10$ & $0 / 10$ \\
\hline
\end{tabular}

* cinco tubérculos por muestra

$\begin{array}{ll}\mathrm{N} & =\text { Nacional } \\ \mathrm{I} & =\text { Importada } \\ \text { Numerador } & =\text { número de muestras infectadas } \\ \text { Denominador } & =\text { número total de muestras }\end{array}$

Es importante señalar que las muestras de las clases Prebásica y Básica provenientes de los invernaderos de producción de semilla de Pueblo Hondo, estado Táchira, presentaron ausencia de los virus en estudio, dando confiabilidad al proyecto de producción de semilla dirigido por FONAIAP, al producir semilla de alta calidad que es garantía de una buena producción y productividad; esto también es válido para el cultivar Andinita de producción nacional, al presentar en todas las clases ausencia de los cuatro virus. Al observar los resultados en la Tabla 1 del tipo pasilla, seleccionado por los productores de ambos cultivares, se nota la ausencia de virus, demostrando así la sanidad de este material, lo que significa que se puede utilizar como semilla por más generaciones, ayudando a disminuir los costos de producción.

En los cultivares Kennebec y Sebago para el estado Lara, también se presentó el virus $\mathrm{S}$ con mayor frecuencia, seguido en menor proporción por la infección doble PVX + PVS. En las clases Básica y Certificada Importada del 
cultivar Sebago la presencia del virus se detectó en tres y cinco muestras respectivamente y para PVX + PVS en una y cuatro muestras (Tabla 2). Resultados similares fueron observados en la clase Certificada Importada de Kennebec con siete muestras positivas (Tabla 2); estos resultados en la semilla importada desde el Canadá, corroboran que dicho material no es totalmente sano, lo que traería como consecuencia la diseminación aún mayor del virus, al seleccionar como semilla tubérculos provenientes de este material, permitiendo la perpetuación del virus.

La muestra tomada de la clase Certificada Nacional de la variedad Kennebec en un campo semillerista no presentó ninguno de los cuatro virus demostrando así la sanidad del material a nivel del tubérculo exigido en las normas de tolerancia del SENASEM (Servicio Nacional de Semilla).

Las diez muestras tomadas en la clase Prebásica en el cultivar Kennebec en los invernaderos de producción de semilla en Cubiro, revelaron la presencia del PVS en seis muestras y la infección PVX + PVS en cuatro muestras (Tabla 2). La semilla se pudo haber contaminado en el manipuleo de traslado al laboratorio o hubo un posible error en la corrida de la prueba serológica para esa placa, debido a que en el material restante llevado a experimento en el campo los resultados no coinciden. Además de esta semilla, se sembraron 8,000 tubérculos a nivel de invernaderos y se tomó una muestra de 1,000 plantas. Se practicó serología a cada planta y no se detectó ninguno de los cuatro virus.

Tabla 2 Muestras infectadas y sanas de brotes de tubérculos, cultivares Kennebec y Sebago. Cubiro, Estado de Lara, 1991.

\begin{tabular}{|c|c|c|c|c|c|c|}
\hline \multirow[b]{2}{*}{ Variedad } & \multirow{2}{*}{ Clases de semilla } & \multicolumn{2}{|c|}{ Muestras* } & \multicolumn{3}{|c|}{ Muestras Infectadas y Sanas } \\
\hline & & $\mathrm{N}^{\circ}$ & PVX & PVS PVX+PVS & PVY & PLRV \\
\hline \multirow[t]{3}{*}{ Sebago } & Básica & 10 & $0 / 10$ & $3 / 10 \quad 1 / 10$ & $0 / 10$ & $0 / 10$ \\
\hline & Certificada & 10 & $0 / 10$ & $5 / 10 \quad 4 / 10$ & $0 / 10$ & $0 / 10$ \\
\hline & Genética (Prebásica) & 10 & $0 / 10$ & $6 / 10 \quad 4 / 10$ & $0 / 10$ & $0 / 10$ \\
\hline \multirow[t]{2}{*}{ Kennebec } & Certificada $(\mathrm{N})$ & 10 & $0 / 10$ & $0 / 10 \quad 0 / 10$ & $0 / 10$ & $0 / 10$ \\
\hline & Certificada (I) & 10 & $0 / 10$ & $7 / 10 \quad 0 / 10$ & $0 / 10$ & $0 / 10$ \\
\hline
\end{tabular}

* Cinco tubérculos por muestra

$\begin{array}{ll}\mathrm{N} & =\text { Nacional } \\ \mathrm{I} & =\text { Importada } \\ \text { Numerador } & =\text { número de muestras infectadas } \\ \text { Denominador } & =\text { número total de muestras }\end{array}$




\section{REFERENCIASBIBLIOGRÁFICAS}

1. Abad, J. 1986. Los virus: su influencia en la producción de papa y virus que afectan a la papa en Perú. En: Principales plagas y enfermedades de la papa en el Perú. Demetrio Untiveros Ed. INIPA, Lima, Perú. p. 116 148.

2. Achutegui, B. A. 1982. Caracterizaciones y huéspedes alternos del virus $\mathrm{X}$ de la papa. Tesis ingeniero agrónomo, Facultad de Agronomía UCV, Maracay, Venezuela, p. 53.

3. Bagnall, R. H. 1980. Virus S. En: Hooker, W. (Ed). Compendio de enfermedades de la papa. Lima, Centro Internacional de la Papa. p. 105 106.

4. Babttari, E. E.; Franc, G. D. 1982. Enzyme-linked immunosorbent assay with single or combined antisera for viruses and $\mathrm{X}$ in potato tubers and plants. Am. Potato J.59:375-387.

5. Beemster, A. B. R.; Boxx, J. A. D. 1987. Survey of properties and symptoms In: Viruses of potatoes and seed potato production. J.A. de Bokx, J. P. M. And Van der Want. (Ed.) 2da. Ed. Wageningen, Center for Agricultural Publishing and Documentation. p. 84-113

6. Clark, M. F.; Adams, A. N. 1977. Characteristics of the microplate method of enzyme-linked inmunosorbent assay for the detection of plant viruses. J. Gen. Virol. 34:475-483

7. Debrot, E. A.; Lastra, R.; Ladera, P. 1080. El virus X de la papa en Venezuela. Rev. Fac. Agron. (Maracay). 11 (l-4):63-77

8. Debrot, E. A. 1975. El virus del enrollamiento de las hojas de papa (potato leaf roll virus) en Venezuela. Agronomía Tropical (Venezuela). 25(2): 107-116

9. Debrot, E.A.; De La Rosa, M. 1980. Identificación del virus Y en muestras de papa de los Andes Venezolanos. Agronomía Tropical (Venezuela). (29) 5:399-411

10. Escobar, M. L. J. 1982. Características y huéspedes alternos del virus Y de la papa. Tesis ingeniero agrónomo, Maracay, Facultad de Agronomía de la UCV. p. 32

11. Fribourg, C. E. 1980. Historia y distribución de virus de papa en América Latina. Fitopatología (Perú). 15:13-24 
12. Hooker, W. J. 1982. Enfermedades virosas de la papa. Boletín de Información Técnica 19. Lima, Perú. Centro Internacional de la Papa (CIP). p. 17

13. Horton, D. 1987. Underground Crops: Long-term trends in production of roots and tubers. Morriton, A.R., USA; Winrock Internacional, p. 10

14 Maat, D. Z. Y Huttinga. 1987. Serology In: Viruses of potatoes and seed potato production. J. A. De Bokx, J. P. M. Van der Want. (Ed.) 2nd. ed. Wageningen, Centre for Agricultural Publishing and Documentation. p. $45-55$

15. Ortega, C. E. 1989. Producción de semilla de papa en Venezuela. $\underline{E n}$ : Curso sobre Producción de papa. Barquisimeto, Venezuela. FONAIAP Estación Experimental Lara. PRACIPA. p. 1-43

16. Ortega, C. E. 1988. Producción de semilla de papa en Venezuela. $\underline{E n}$ : Producción de semilla de papa y transferencia de tecnología en Venezuela. FONAIAP-PRODETEC-CEE-JUNAC-PADT, RuralPRACIPA-CIP-Gobernación-IAN. p. 1-27

17. Salazar, L. F. 1986. Detección de virus en la producción de semilla de papa. Boletín de Información Técnica 18. Centro Internacional de la Papa (CIP). Lima, Perú. p. 14

18. Wetter, C. 1971. Potato Virus S. C.M.I./A.A.B. Descriptions of Plant Viruses. $\mathrm{N}^{\circ} 60$. p.3 